\title{
KRONIKA
}

\section{SPRAWOZDANIE Z DZIAŁALNOŚCI BIBLIOTEKI NAUKOWEJ PAU I PAN \\ W KRAKOWIE \\ za okres od 1 I do 31 XII 2018 r.}

\section{SPRAWY ORGANIZACYJNE I STRUKTURA BIBLIOTEKI}

Podział wewnętrzny Biblioteki, zgodnie z brzmieniem Ordynacji, kształtował się następująco:

Dział I: Gromadzenie i Uzupełnianie Zbiorów

Dział II: Opracowanie Druków

Dział III: Udostępnianie, Przechowywanie i Konserwacja Zbiorów

Dział IV: Gabinet Rycin

Dział V: Zbiory Specjalne

Dział VI: Pracownia Reprograficzna.

Obsługę finansowo-księgową Biblioteki prowadziła księgowość PAU. Sprawy personalno-kadrowe od 1 V 2017 do 30 IV 2018 prowadziła pani mgr Agnieszka Gurbiel, a po niej obsługę kadrową przejęła pani mgr Halina Pazdan-Olesińska.

\section{RADA NAUKOWA I KOLEGIUM BIBLIOTEKI}

Od 27 IV 2015 roku działa powołana na lata 2015-2018 (zgodnie z porozumieniem władz PAU i PAN) Rada Naukowa w następującym składzie:

ze strony PAU:

1. Prof. dr hab. Krzysztof Baczkowski - Wydział II PAU

2. Prof. dr hab. Szczepan Biliński - sekretarz generalny PAU

3. Dr Karolina Grodziska - dyrektor Biblioteki Naukowej PAU i PAN w Krakowie

4. Prof. dr hab. Jan Machnik - Wydział II PAU

5. Prof. dr hab. Jan M. Małecki - Wydział II PAU

6. Prof. dr hab. Adam Małkiewicz - Wydział I PAU

7. Prof. dr hab. Jan Michalik - Wydział I PAU

8. Prof. dr hab. Jacek Purchla - Wydział II PAU, dyrektor Międzynarodowego Centrum Kultury w Krakowie

9. Prof. dr hab. Michał Turała - Wydział III PAU;

10. Prof. dr hab. Jerzy Wyrozumski - delegat Walnego Zgromadzenia PAU,

ze strony PAN:

1. Dr hab. Ewa Danowska - starszy kustosz dyplomowany Biblioteki Naukowej PAU i PAN w Krakowie 
2. Mgr Ewa Dobrzyńska-Lankosz - dyrektor Biblioteki Głównej AGH

3. Prof. dr hab. Julian Dybiec - Komisja Historii Nauki PAU

4. Prof. dr hab. Irena Homola-Skąpska - Instytut Historii PAN

5. Mgr Małgorzata Kremer - wicedyrektor Biblioteki Naukowej PAU i PAN w Krakowie

6. Mgr Krzysztof Krużel - kierownik Gabinetu Rycin Biblioteki Naukowej PAU i PAN w Krakowie

7. Dr Rita Majkowska - dyrektor Archiwum Nauki PAN i PAU

8. Prof. dr hab. Edward Nęcka - wiceprezes Polskiej Akademii Nauk, Instytut Psychologii UJ

9. Prof. dr hab. Zdzisław Pietrzyk - dyrektor Biblioteki Jagiellońskiej

10. Prof. dr hab. Ryszard Tadeusiewicz - Katedra Automatyki i Inżynierii BiomedycznejAGH.

Posiedzenie Rady Naukowej odbyło się 21 III 2018 r. Obrady otworzył prof. dr hab. Z. Pietrzyk. W dyskusji skupiono się na problemach finansowych Biblioteki, zwrócono uwagę na bardzo niski budżet oraz brak partycypacji PAN w kosztach utrzymywania Biblioteki. Poruszono problem braku miejsca na dochodzące zbiory. Podkreślano mocną pozycję Biblioteki w środowisku naukowym, chwalono sprzyjającą atmosferę do pracy, pozytywnie oceniono działalność naukową. Rozmawiano o bezcennej wartości zbiorów będących majątkiem narodowym. Wyrażono podziękowania za intensywne wprowadzanie zbiorów do katalogu komputerowego. Kolejne posiedzenia Rady Naukowej poświęcone wyborowi nowego dyrektora Biblioteki odbyły się 9 XI i 14 XII 2018 r. Obradom przewodniczył prof. dr hab. Z. Pietrzyk. Przyjęto regulamin konkursu na stanowisko dyrektora, ustalono termin konkursu i powołano z grona Rady Komisję Konkursową w składzie: prof. dr hab. Z. Pietrzyk, prof. dr hab. S. Biliński, prof. dr hab. J. Purchla, dr K. Grodziska. Rada w dniu 14 XII przyjęła sprawozdanie komisji konkursowej, zatwierdziła przedstawionego kandydata i przesłała propozycję wraz z uzasadnieniem Prezesowi PAU, który z dniem 1 II 2019 powołał na to stanowisko panią dr Agnieszkę Fludę-Krokos.

W roku 2018 odbyły się 2 posiedzenia kolegium, w skład którego wchodzili dyrektor Biblioteki, jej wicedyrektor i kierownicy działów. Omawiano sprawy organizacyjne, obsługę kadrową przez nową osobę w Biurze PAU, sprawy dotyczące przestrzegania regulaminu pracy i sprawy lokalowe. Ustalano dyżury pracowników w magazynie starych druków w trakcie prac przy demontażu starych i montażu nowych regałów oraz kolejność przenoszenia i rozpakowywania zbiorów starych druków i kartografii.

\section{SKŁAD OSOBOWY BIBLIOTEKI}

\section{SPIS PRACOWNIKÓW BIBLIOTEKI}

Dyplomowani bibliotekarze:

Starszy kustosz dyplomowany - dr hab. Ewa Danowska

Pracownicy służby bibliotecznej:

a) starsi kustosze: mgr Monika Fiutowska, dr Karolina Grodziska, mgr Małgorzata Kremer, mgr Krzysztof Krużel, dr Wojciech Lipowski, mgr Jan Motyka, mgr Lucyna Pyrzowska, mgr Jacek Wojtowicz

b) kustosze: mgr Magdalena Adamska, mgr Bożena Kalicka, dr Elżbieta Knapek, mgr Bożena Korniak, mgr Małgorzata Turczak, mgr Kamila Woźniak

c) starsi bibliotekarze: mgr Iwona Branc, dr Anna Olszewska, mgr Urszula Orłowska-Węgiel;

d) bibliotekarze: mgr Teresa Bobek, mgr Jakub Chojnacki, mgr Julia Czapla, mgr Maciej Gawłowski, mgr Łukasz Łukawski, mgr Maria Radziszewska

e) młodsi bibliotekarze: mgr Aneta Kołodziejczyk, lic. Magdalena Pacyna, mgr Bartłomiej Stempin, mgr Piotr Świątczak, mgr Maria Urgacz 
f) starsi magazynierzy: mgr inż. Andrzej Łakomski, Stanisława Suchanik

g) młodsi magazynierzy: Bartłomiej Panek

h) pracownicy administracyjni:

- starszy referent: Celina Dutkiewicz

- starszy woźny: Barbara Krzywdzińska

- woźny: Kinga Krzywdzińska.

Pracownicy niepełnozatrudnieni:

- mgr Jan Motyka (1/2 etatu)

- dr Anna Olszewska (1/2 etatu)

- mgr Lucyna Pyrzowska (1/4 etatu do 31 XII 2018).

Zatrudnienie na dzień 1 I 2018 wynosiło 36 osób, tj. 34 1⁄/4 etatu, a w dniu 31 XII 2018 wynosiło 34 osoby, tj. 32 i $1 / 4$ etatu, w tym:

- 31 osób pracuje na pełen etat, a 3 osoby pracują w niepełnym wymiarze godzin (łącznie to $1 \mathrm{i} 1 \frac{1}{4}$ etatu)

- 2 osoby zatrudnione są na czas określony, pozostali pracownicy mają stałe umowy o pracę. W roku 2018 rozwiązano umowy o pracę z 6 osobami, w tym z 1 osobą niepełnozatrudnioną. W ciągu roku przyjęto do pracy 3 osoby. Od kwietnia 2018 dwie osoby pozostawały na urlopie rodzicielskim.

W ramach oszczędności budżetowych nieobsadzone na koniec 2018 roku pozostały 4 pełne etaty i 3/4 etatu oraz dwa etaty osób na urlopie rodzicielskim, a zaoszczędzone środki przeznaczone zostały na remonty magazynów bibliotecznych.

W Bibliotece Polskiej w Paryżu okresowo pracowała pani mgr Lucyna Pyrzowska (1 II - 30 IV, 28 VIII - 8 IX, 23 X - 15 XII).

Praktyki studenckie odbył Jan Gordziejew.

\section{OBSADA POSZCZEGÓLNYCH DZIAŁÓW}

Dyrektor: dr Karolina Grodziska

Wicedyrektor: mgr Małgorzata Kremer

Dział I: Gromadzenie i Uzupełnianie Zbiorów

Kierownik: mgr Urszula Orłowska-Węgiel

Zastępca: dr Wojciech Lipowski

Pracownicy: mgr Aneta Kołodziejczyk (od 1 do 31 X 2018), mgr Łukasz Łukawski (do 31 VII 2018), lic. Magdalena Pacyna (od 1 XI 2018), mgr Bartosz Wrona (od 1 IV do 19 VI 2018)

Dział II: Opracowanie Druków

Kierownik: mgr Anna Dusza-Bielenin (do 30 IX 2018), następnie vacat

Zastępca: mgr Joanna Gąsiorowska (do 25 IX 2018), mgr Małgorzata Turczak (od 1 X 2018)

Kierownik zarządzający systemem VTLS/VIRTUA: mgr Monika Fiutowska (urlop macierzyński od 29 III 2018 do 27 III 2019)

Pracownicy: mgr Iwona Branc, mgr Aneta Kołodziejczyk (od 1 do 30 XI 2018), mgr Lucyna Pyrzowska (1/4 etatu od 4 I 2016 do 31 XII 2018), mgr Małgorzata Turczak, mgr Kamila Woźniak

Dział III: Udostępnianie Zbiorów

Kierownik: mgr Bożena Kalicka

Zastępca: vacat (od 1 IV 2016) 
Pracownicy: Barbara Krzywdzińska, mgr Aneta Kołodziejczyk (od 1 XII 2018), mgr inż. Andrzej Łakomski, Bartłomiej Panek, Stanisława Suchanik, mgr Małgorzata Poznańska (do 17 XII 2018), mgr Bartłomiej Stempin, mgr Piotr Świątczak, mgr Maria Urgacz

Dział IV: Gabinet Rycin

Kierownik: mgr Krzysztof Krużel

Zastępca: vacat

Pracownicy: mgr Magdalena Adamska, mgr Teresa Bobek (urlop macierzyński od 21 IV 2018 do 20 IV 2019), Kinga Krzywdzińska, mgr Jan Motyka (1/2 etatu), dr Anna Olszewska (1/2 etatu)

Dział V: Zbiory Specjalne

Kierownik: mgr Joanna M. Dziewulska (do 30 VII 2018), dr Elżbieta Knapek (od 1 VIII 2018)

Zastępca: dr Elżbieta Knapek (do 30 VII 2018), mgr Julia Czapla (od 1 VIII 2018)

Pracownicy: dr hab. Ewa Danowska, mgr Maciej Gawłowski, mgr Bożena Korniak, mgr Łukasz Łukawski (od 1 VIII 2018), mgr Maria Radziszewska, mgr Jacek Wojtowicz

Dział VI: Pracownia Reprograficzna

mgr Jakub Chojnacki

Sekretariat: Celina Dutkiewicz (do 27 XII 2018)

\section{BUDŻET BIBLIOTEKI}

W 2018 roku budżet Biblioteki pozostał w wysokości 260 000,00 zł. W kwocie tej mieszczą się zarówno wydatki na działalność statutową, jak i ogólnotechniczną. Gratyfikację świąteczną wypłacono w wysokości odpowiadającej średnim miesięcznym poborom pracownika, natomiast kolejny rok nie wypłacono regulacji inflacyjnej. Dokonano 13 drobnych korekt uposażeń w wysokości od 100,00 do 200,00 zł. Były one możliwe dzięki przesunięciom pracowników między działami, po przejściu na emeryturę doświadczonych pracowników.

W składzie Komisji Socjalnej PAU działali ze strony Biblioteki: mgr Maciej Gawłowski i mgr Maria Radziszewska.

Pracownicy Biblioteki otrzymali dofinansowanie z ZFŚS w łącznej kwocie 50 457,00 zł, w tym m.in.: dofinansowanie pobytu 9 dzieci w żłobkach i w przedszkolach na kwotę 7694,00 zł, wypoczynku 2 dzieci na kwotę 840,00 zł, paczki mikołajowe otrzymało 18 dzieci w wysokości 828,00 zł. Pracownicy, którzy złożyli wniosek o dofinansowanie wypoczynku (31 osób), otrzymali ekwiwalent pieniężny za tzw. wczasy pod gruszą na łączną kwotę 22900,00 zł. Zapomogi świąteczne dla 36 osób wyniosły 7 800,00 zł. Przyznano 3 zapomogi losowe na kwotę 4400,00 zł i 6 zapomóg ekonomicznych na kwotę 5 995,00 zł.

\section{INWESTYCJE, KOMPUTERYZACJA, PLAN OCHRONY ZBIORÓW}

$\mathrm{W}$ magazynie starych druków zamontowano nowe regały metalowe i nowy mapnik w formacie A0 oraz wykonano nowe oświetlenie - prace te finansowano ze środków własnych Biblioteki (tj. z zamrożonych etatów). Wymieniono wszystkie czujki sygnalizacji systemu przeciwpożarowego i podłączono nowy system powiadamiania ppoż. Na III piętrze wymieniono pięć kamer systemu TTV i kilka czujek z systemu antywłamaniowego. Dla Działu Zbiorów Specjalnych zakupiono specjalną folię świecącą umożliwiającą odczytanie znaków wodnych i struktury papieru. Zakupiono drobny sprzęt komputerowy (klawiatury, myszki itp.) oraz oprogramowanie antywirusowe (kontynuacja licencji do X 2020 r.). 
Kontynuowano oklejanie książek specjalnym etykietami alarmowymi.

W 2018 r. trwały dalsze prace pozwalające na wypełnienie zaleceń Krajowej Rady Bibliotecznej dotyczących zaliczenia części zbiorów Biblioteki do Narodowego Zasobu Bibliotecznego.

\section{STAN LICZBOWY ZBIORÓW}

Stan liczbowy zbiorów w dniu 31 XII 2018 r.

\begin{tabular}{|c|c|}
\hline $\begin{array}{l}\text { Liczba druków ogólem } \\
\text { w tym: }\end{array}$ & 562460 wol. \\
\hline wydawnictwa ciągłe & 347836 wol. \\
\hline wydawnictwa zwarte & 214624 wol. \\
\hline $\begin{array}{l}\text { Zbiory specjalne ogółem } \\
\text { w tym: }\end{array}$ & 177374 wol. i jedn. inw. \\
\hline stare druki & 17222 \\
\hline rękopisy & 16608 \\
\hline dyplomy pergaminowe & 633 \\
\hline druki ulotne & 11145 \\
\hline kartografia & 12226 \\
\hline mikrofilmy pozytywowe & 2739 \\
\hline mikrofilmy negatywowe & 624 \\
\hline grafika & 99181 \\
\hline rysunki & 2266 \\
\hline ekslibrisy & 14639 \\
\hline zbiory muzealne & 91 jedn. inw. \\
\hline Ogółem liczba zbiorów & 739834 wol. i jedn. inw. \\
\hline
\end{tabular}

W 2010 r. zdecydowano, że egzemplarze archiwalne zbiorów specjalnych będą przechowywane na dyskach przenośnych. W 2018 r. zdigitalizowano 18 jedn. rękopisów, a przechowywane dotąd na płytach CD wtórniki zbiorów specjalnych również przegrano na dyski przenośne. 


\section{DZIAŁ GROMADZENIA I UZUPEŁNIANIA ZBIORÓW}

Podstawowymi źródłami wpływów do Biblioteki pozostają, jak w ubiegłych latach, wymiana międzynarodowa i krajowa oraz dary. Wymiana prowadzona jest poprzez wysyłkę tytułów publikowanych przez Polską Akademię Umiejętności, Oddział Polskiej Akademii Nauk w Krakowie, wydawnictwa własne Biblioteki i dary od wydawców.

Liczba wysyłanych egzemplarzy zależna jest od dotychczasowej liczby kontrahentów i waha się od 1 do 225 egz. (81 tytułów) wydawanych przez PAU i od 42 do 306 egz. (4 tytuły) wydawanych przez Oddział PAN. Otrzymano z Polskiej Akademii Umiejętności wydawnictwa w kwocie 39 227,14 zł, a wartość wydawnictw z Oddziału PAN w Krakowie wyniosła 16 155,00 zł. Wartość wydawnictw własnych (42 tytuły) wysłanych na wymianę wynosiła 11 308,13 zł. Na wymianę zaprenumerowano i zakupiono również 6 tytułów na kwotę 2 820,36 zł (wysłano od 1 do 59 egz.).

$\mathrm{Z}$ otrzymanych w darze na wymianę wydawnictw od dr K. Grodziskiej, prof. dr. hab. S. Grodziskiego, redakcji czasopisma Acta Zoologica Cracoviensia, Polskiego Towarzystwa Ceramicznego oraz Bronisława Nowaka z firmy Alladyn (na kwotę 2920,00 zł), wysłano 5 tytułów (od 6 do 45 egz.).

Łącznie szacowany koszt wydawnictw wysyłanych na wymianę to kwota $\mathbf{7 2} \mathbf{4 4 0 , 6 3}$ zl. Opłaty pocztowe za wysyłkę na wymianę wyniosły $24078,94 \mathrm{zł}$.

Cztery biblioteki zagraniczne zgłosiły rezygnację z wymiany (m.in. The Field Museum of Natural History, The Chemical Society of Japan). Nawiązano współpracę z dwoma instytucjami: Institut für Ostrecht w Regensburgu i Institutul de Studii Sud-Est Europene w Bukareszcie.

Struktura wymiany zagranicznej i krajowej (w zeszytach)

\begin{tabular}{|l|c|c|c|}
\hline & Wymiana zagraniczna & Wymiana krajowa & Razem \\
\hline Wydawnictwa PAU & 670 & 793 & 1463 \\
\hline Wydawnictwa PAN & 475 & 19 & 494 \\
\hline $\begin{array}{l}\text { Dary od autorów } \\
\text { i wydawców }\end{array}$ & 13 & 49 & 62 \\
\hline Wydawnictwa własne & 387 & 348 & 735 \\
\hline Prenumerata i kupno & 34 & 54 & 88 \\
\hline \multicolumn{1}{|c|}{ Razem } & $\mathbf{1 5 7 9}$ & $\mathbf{1 2 6 3}$ & $\mathbf{2 8 4 2}$ \\
\hline
\end{tabular}

Łącznie wysłano $\mathbf{2 8 4 2}$ zeszyty.

W roku 2018 prowadzono wymianę z 480 instytucjami w 62 krajach i 132 instytucjami w Polsce.

Struktura terytorialna wymiany zagranicznej

\begin{tabular}{|l|c|c|c|}
\hline \multicolumn{1}{|c|}{ Kontynent } & Liczba krajów & Instytucje & Procent udziału wym. \\
\hline Europa & 37 & 363 & 75,72 \\
\hline Afryka & 5 & 7 & 1,44 \\
\hline Ameryka & 8 & 43 & 8,84 \\
\hline Australia i Oceania & 2 & 10 & 2,05 \\
\hline Azja & 10 & 57 & 12,03 \\
\hline \multicolumn{1}{|c|}{ Razem } & $\mathbf{6 2}$ & $\mathbf{4 8 0}$ & $\mathbf{1 0 0}$ \\
\hline
\end{tabular}


Łącznie otrzymano z wymiany $\mathbf{1 0 7 3}$ woluminy, w tym z wymiany zagranicznej 707 i z wymiany krajowej 366 oraz $4 \mathrm{CD}$.

Równocześnie Biblioteka udostępnia w Czytelni Głównej w systemie on-line 150 tytułów wydawnictw, w tym 126 tytułów czasopism otrzymywanych z wymiany międzynarodowej oraz 24 tytuły krajowe.

Szacunkowa wartość publikacji, które wpłynęły z wymiany zagranicznej i krajowej w $2018 \mathrm{r}$. wyniosła 117 970,11 zł, przy kosztach własnych z budżetu Biblioteki 41 137,43 zł (koszty wysyłki 24 078,94 zł; wartość wydawnictw własnych, darów i zakupów 17 058,49 zł).

W 2018 roku zakupiono do zbiorów 274 tytuły wydawnictw zwartych o wartości $\mathbf{1 3} \mathbf{9 0 9 , 0 0}$ zł. Prenumerata krajowa to 82 tytuły, a zagraniczna 8 tytułów, na łączną kwotę $\mathbf{1 7} \mathbf{3 2 0 , 2 8} \mathrm{zł}$.

Łączny przyrost księgozbioru w roku 2018

(wymiana, zakup, dary, wydawnictwa własne)

\begin{tabular}{|c|c|c|}
\hline & Przyrost księgozbioru & W tym wymiana \\
\hline Wydawnictwa zwarte & 1140 & 303 \\
\hline Wydawnictwa ciągłe & 1377 & 770 \\
\hline Płyty CD & 8 & 4 \\
\hline Lącznie & $\mathbf{2 5 2 5}$ & $\mathbf{1 0 7 7}$ \\
\hline
\end{tabular}

Elektroniczne bazy danych:

W 2018 r. dostępne były w czytelniach Biblioteki 3 bazy danych: ACADEMICA, Lex Omega, Wielka Genealogia Minakowskiego.

W roku 2018 Biblioteka otrzymała w darze do swoich zbiorów 961 tomów wydawnictw o wartości szacunkowej 16 088,09 zł (krajowych 776 i zagranicznych 176 tomów oraz 4 egz. CD/DVD).

Wśród darczyńców szczególne podziękowania należą się prof. Szczepanowi Bilińskiemu, dr Karolinie Grodziskiej, prof. Stanisławowi Grodziskiemu, Alinie Kalczyńskiej, Mirosławowi Kruszyńskiemu, prof. Joachimowi Śliwie, prof. prof. dr hab. Bożennie i Jerzemu Wyrozumskim za ofiarowanie wielu świetnych pozycji.

Za ofiarowanie kolejnej serii dwudziestu cennych miedziorytów szczególne podziękowania należą się prof. Krzysztofowi Skórczewskiemu, a Janowi Motyce i prof. Ewie Zawadzkiej za dary grafik współczesnych.

Podziękowania za przekazane wydawnictwa należą się też Polskiej Akademii Umiejętności, Polskiej Akademii Nauk, Instytutowi Pamięci Narodowej i Towarzystwu Przyjaciół Bronowic.

Stypendyści Fundacji Lanckorońskich ofiarowali do zbiorów 4 publikacje.

Rozesłano listy dubletów, a zamówione wydawnictwa, tj. 202 wol. z zasobów Biblioteki i 2231 wol. z zapisu testamentowego prof. Marii Karpluk, przesłano do 24 instytucji, m.in. do: Biblioteki Narodowej, Biblioteki Jagiellońskiej, Biblioteki MCK w Krakowie, Biblioteki UP JP II w Krakowie, Biblioteki Uniwersyteckiej w Warszawie, Południowo-Wschodniego Instytutu Naukowego w Przemyślu, Centralnej Biblioteki Białoruskiej Akademii Nauk w Mińsku, Uniwersytetu Masaryka w Brnie, Slovensky Ustav CR w Pradze, Przykarpackiego Narodowego Uniwersytetu w Iwano-Frankowsku, Muzeum Sztuki Dawnej Książki Ukraińskiej we Lwowie, Biblioteki im. W. Stefanyka we Lwowie, Korolenko Library w Charkowie, Rosyjskiej Biblioteki Narodowej w Moskwie.

Kolejne 787 wol. z zapisu testamentowego prof. Marii Karpluk, zamówionych przez Rosyjską Akademię Nauk w Petersburgu i Universitá degli Studi di Udine, czeka na wysyłkę.

Z wymiany dubletów pozyskano 97 wol. o łącznej szacunkowej wartości 405,00 zł. 
W Dziale prowadzono systematycznie dokumentację prac bieżących (księgi, korespondencja, faktury), wiele formalności związanych z wymianą, zakupami i prenumeratą prowadzono za pośrednictwem poczty elektronicznej. Przyjmowano, rozdzielano i wydawano korespondencję do instytucji w kompleksie gmachów przy ul. Sławkowskiej 17 i św. Jana 22. Pakowano i wysyłano książki na wymianę międzybiblioteczną. Wysyłano także w ramach umowy z Pocztą Polską S.A. wszystkie egzemplarze obowiązkowe wydawnictw PAU przekazywane przez dział wydawnictw. Na prośbę działu wydawnictw i prof. Raimo Pullata spakowano i wysłano do Tallina nakład książki Świat rzeczy mieszkańców Tallina autorstwa Raimo Pullata.

W roku 2018 przedłużono z Pocztą Polską, na kolejne 5 lat, dwie umowy na odbiór przesyłek.

Dział miał poważne trudności kadrowe, od 1 VI Łukasz Łukawski odbywał szkolenie w Dziale Opracowania Druków, a od 1 VIII został przeniesiony do Działu Zbiorów Specjalnych. Wszystkie prace związane z prowadzeniem rejestracji wydawnictw, prowadzeniem ksiąg akcesyjnych (wcześniej G. Drajewicz-Bobek), pakowanie i wysyłkę oraz pełną obsługę pocztową całej korespondencji (wcześniej Ł. Łukawski) przejęli U. Orłowska-Węgiel i W. Lipowski.

Dr Wojciech Lipowski sprawował opiekę redakcyjną nad stroną internetową Biblioteki, kontynuował współpracę z platformą Portal Czasopism Naukowych Uniwersytetu Jagiellońskiego w zakresie prac dotyczących elektronicznej wersji Rocznika Biblioteki Naukowej PAU i PAN.

Szkolenie wewnętrzne odbyły 3 osoby, a praktykę studencką 1 osoba.

Zob. Dział XIV (działalność dydaktyczna), XV (współpraca z innymi Bibliotekami), XVII (podnoszenie kwalifikacji, szkolenia), XVIII (odczyty, konferencje), XXI (wykaz prac drukowanych).

\section{DZIAŁ OPRACOWANIA DRUKÓW}

1. Katalogowanie alfabetyczne

Pracami katalogowymi objęto bieżące wpływy druków zwartych i ciągłych:
a) wydawnictwa zwarte
1279 wol.
b) wydawnictwa ciągłe
164 wol.
c) dopisano do istniejących kart
1720 wol.

łącznie:

3163 wol.

Dla wydawnictw seryjnych szczegółowo rozpisywanych w systemie komputerowym nie drukuje się kart, dla poszczególnych tomów monograficznych, do tradycyjnego katalogu alfabetycznego. Od stycznia 2016 roku nie drukuje się również kart dla wydawnictw zwartych. Karty katalogowe drukuje się w dalszym ciągu dla wydawnictw zwartych wielotomowych, wydawnictw ciągłych i serii wydawniczych (karty główne). W 2018 roku wydrukowano:
a) do katalogu alfabetycznego
447
b) do innych katalogów
252

łącznie:

699 kart.

\section{Opracowanie komputerowe}

Opracowaniem komputerowym objęte są bieżące wydawnictwa zwarte, serie wydawnicze oraz retrospektywnie katalogowane wydawnictwa z dwóch pierwszych tomów inwentarza. Osobno prowadzone są prace nad katalogowaniem zasobu rękopisów i starych druków (zob. Dział Zbiorów Specjalnych).

W „Bazie KRAK 8” sporządzono w 2018 roku:

a) 1395 rekordów bibliograficznych w NUKAT

b) 4384 rekordy egzemplarza 
c) 369 wzorcowych rekordów haseł przedmiotowych w języku KABA (w tym nowych 59)

d) 221 rekordów zasobu, dopisano 3137 wol. oraz poprawiono 84

e) użyto 1274 hasła przedmiotowe, które posłużyły opracowaniu 879 pozycji

f) naniesiono poprawki w 227 rekordach w NUKAT.

Skopiowano do bazy lokalnej 3613 rekordów bibliograficznych. Trwa na bieżąco opracowywanie dokumentów elektronicznych.

Do Centralnej Kartoteki Haseł Wzorcowych sporządzono:

a) 856 rekordów wzorcowych nazw osobowych i korporatywnych

b) 20 rekordów wzorcowych imprez

c) 39 rekordów wzorcowych tytułów serii

d) 111 rekordów wzorcowych autor/tytuł

e) 45 rekordów wzorcowych tytułów ujednoliconych i formalnych

f) 35 rekordów wzorcowych ujednoliconych.

Łącznie 1106 rekordów wzorcowych i 369 rekordów KABA.

Ponadto poprawiono 213 rekordy w CKHW.

Ogólna liczba nowych rekordów wzorcowych (CKHW i KABA) wynosi 1475.

Kontynuowano współpracę z bibliotekami współtworzącymi Bazę KRAK 8. Stan naszych zbiorów w tej bazie 31 XII 2018 wynosił:
a) rekordów bibliograficznych
99257
b) rekordów egzemplarza
107148
c) rekordów zasobu
4815
d) rekordów KHW
53000.

Kolejny rok kontynuowano retrospektywne katalogowanie komputerowe wydawnictw, skupiając się na pierwszym tomie inwentarza, obejmującym sygnatury od 1 do 5000 . Opracowano w systemie komputerowym sygnatury: 1396 III-1510 I oraz 1655 I, 1758 II, 1779 II, 1785 II-1786 II, 1789 II, 1790 II-1791 II, 1853 II, 1884 II.

Prace objęły 170 sygnatur w 2704 wol. Pozycje te, wydawane w większości w XIX wieku, zazwyczaj nie są notowane w bazach bibliotecznych, ich opis zgodny z dzisiejszymi normami wymaga bardzo wiele czasu, wiąże się z koniecznością przeprowadzenia melioracji, zabezpieczania przed zniszczeniem poszczególnych egzemplarzy. Kontynuowano także rozpoczęte w 2017 r. prace nad opracowaniem retrospektywnym druków z pierwszego inwentarza druków zwartych, obejmującego sygnatury od 10001 do 15 000. Prace objęły sygn. 11401 II-12 900 II oraz 14 801-14 923 IV i 14 992-15 000 IV. Opracowano 800 sygnatur, tj. 1770 wol., m.in.: Sammlung der besten Reisebeschreibungen, Brünn 1787, Archaeologia: or, Miscellaneous Tracts Relating to Antiquity, London 1870-1873, Versammlung Deutscher Philologen, Wiedeń 1893, Aus Natur und Geisteswelt, Leipzig 1906-1920 - 35 wol., Przewodnik po ziemiach Małopolskich, Kraków 1921. Wśród XIX wiecznych druków znaleziono również 3 pozycje współoprawne ze starymi drukami, a także dokumenty współoprawne introligatorsko, które nie były ani skatalogowane, ani wpisane do inwentarza.

W styczniu 2018 r. NUKAT wprowadził nowe zasady katalogowania, tzw. RDA.

Przeprowadzono migrację do nowej wersji systemu VIRTUA w bazie NUKAT.

Kontynuowano dalsze prace nad bazą autografów i dedykacji w zbiorach Biblioteki, w $2018 \mathrm{r}$. wprowadzono 69 nowych opisów. Obecnie baza liczy 3377 pozycji.

\section{Inwentarz}

Przez księgi inwentarzowe, wspólne dla druków zwartych i wydawnictw ciągłych, przeprowadzono 1333 dzieła w 3163 wol. (w tym wydawnictw zwartych 1217 dzieł w 1279 wol., wydawnictw ciągłych 116 pozycji w 164 wol.). Z ogólnej liczby woluminów 1926 zostało dopisanych do istniejących sygnatur. 
Zmeliorowano, nanosząc poprawki w inwentarzu, wydawnictwa znajdujące się na 30 sygnaturach.

W Bibliotece Polskiej w Paryżu, w ramach projektu Opracowanie katalogów XIX-wiecznych druków wydanych na emigracji i ziemiach polskich ze zbiorów Biblioteki Polskiej w Paryżu i Towarzystwa Historyczno-Literackiego, okresowo pracowała pani mgr Lucyna Pyrzowska.

Szkolenie wewnętrzne odbyło 8 pracowników działów: Zbiorów Specjalnych i Gromadzenia Zbiorów.

Zob. Dział XIII (skontrum), XV (współpraca z innymi Bibliotekami), XVII (podnoszenie kwalifikacji), XVIII (odczyty, konferencje).

\section{DZIAŁ UDOSTĘPNIANIA ZBIORÓW}

\section{Czytelnia Główna}

W Czytelni Głównej odnotowano 1972 odwiedziny, przy czym wydano 337 kart wstępu dla stałych czytelników. Udostępniono 2643 wol. druków zwartych, 2687 wol. wydawnictw ciągłych, 385 mikrofilmów.

Kontynuowano ewidencję czytelników w bazie komputerowej (P. Świątczak, M. Urgacz). Czytelnicy mogli korzystać z dostępu do bieżących czasopism polskich (57 tytułów) i zagranicznych (110 tytułów) oraz czasopism on-line (150 tytułów), komputerowych katalogów bibliotecznych, informacyjnych baz danych, bazy ACADEMICA oraz z bazy LEX Omega. Czytelnia objęta jest siecią Wi-Fi.

Do katalogu elektronicznego wprowadzono 75 rekordów zasobu (B. Kalicka, M. Urgacz, B. Stempin).

W czytelni odbyły się 4 pokazy dla studentów. Systematycznie udzielano wielu wskazówek bibliograficznych.

\section{Katalogi}

Od 2016 roku nie drukuje się kart katalogowych dla wydawnictw zwartych. Również dla wydawnictw seryjnych, szczegółowo rozpisywanych w systemie komputerowym, nie drukuje się kart dla poszczególnych tomów monograficznych. W omawianym okresie do katalogów włączono 447 nowych kart katalogowych. Na bieżąco porządkowano układ kart w skrzynkach (B. Kalicka, M. Urgacz, B. Stempin, P. Świątczak).

Dokonano przeglądu 3925 pozycji z darów, selekcjonując dublety. Udzielono szczegółowych odpowiedzi na 81 pisemnych kwerend dotyczących zbiorów Biblioteki.

$\mathrm{Na}$ stronie internetowej Biblioteki odnotowano 23309 wizyt, podczas których zostały otwarte 68963 strony.

\section{Wypożyczalnia}

Odnotowano 727 wypożyczeń, w tym 62 dla osób indywidualnych i 665 dla bibliotek. Z innych bibliotek wypożyczono 5 wol.

Łącznie zarejestrowanych było w Bibliotece 37 placówek (w tym 24 instytucje zamiejscowe). Konta indywidualne posiadało 46 czytelników.

\section{Magazyny}

W ramach dalszego porządkowania magazynu po malowaniu przeniesiono i ułożono na regałach 526 kartonów książek, dokonując równocześnie zmian w ułożeniu sygnatur.

Z magazynu starych druków przemieszczono paczki z książkami (615) do sąsiednich pomieszczeń, a po ustawieniu nowych regałów przyniesiono je z powrotem. 
Równocześnie pracownicy realizowali na bieżąco zamówienia dla czytelników (1780 wol.) oraz do melioracji w Dziale Opracowania (5877 wol.), wybijali sygnatury, transportowali dary dla Biblioteki (6 transportów), oprawiali uszkodzone egzemplarze i oklejali księgozbiór etykietami zabezpieczającymi.

Do elektronicznej bazy Polskiej Bibliografii Naukowej przenoszono dane tytułowe i bibliografię artykułów z Rocznika Biblioteki... za lata 1955-1956, 1958-1962, 1964-1965, 1967,1969, 1971-1980, 2017, tj. dane z 20 roczników (M. Urgacz, P. Świątczak, B. Stempin).

Do oprawy oddano łącznie 33 wol. Systematycznie tworzono wykaz pozycji wymagających pomocy introligatora (B. Stempin, P. Świątczak). Szkolono nowo przyjętych pracowników (3 osoby).

Praktykę studencką odbyła 1 osoba.

Zob. Dział XIII (skontrum), XV (współpraca z innymi Bibliotekami), XVII (podnoszenie kwalifikacji), XX (konserwacja), XXI (wykaz prac drukowanych).

\section{DZIAŁ ZBIORÓW SPECJALNYCH}

Czytelnia Działu Zbiorów Specjalnych

W czytelni Działu zanotowano 594 odwiedziny. Czytelnicy wypełnili 202 kwestionariusze osobowe dla korzystających z rękopisów i 10 kwestionariuszy dla korzystających ze starych druków.

Udostępniono:

- 747 wol. rękopisów

- 10 pergaminów

- 63 wol. starych druków

- 717 mikrofilmów

- 94 wol. książek.

Stałe dyżury w czytelni pełnili Maciej Gawłowski, Bożena Korniak, Julia Czapla, Maria Radziszewska i Łukasz Łukawski (od 1 VIII).

Wykonano przegląd księgozbioru podręcznego Działu, dokonano licznych przesunięć zbiorów w obrębie pokoi (293 wol.) oraz przeniesień do innych działów (105 wol.), wykonując dla wszystkich pozycji nowe oznaczenie miejsca.

\section{Rękopisy}

Opracowywano w dalszym ciągu spuścizny Jerzego Gota, Antoniego Podrazy oraz materiały z Archiwum Lenkiewiczów. Uporządkowano i opracowano kolekcję kart pocztowych K. Wit-Jóźwik i J. Jóźwika, a także J. Dynowskiego-Balcera (E. Danowska, M. Radziszewska).

Elżbieta Knapek przeprowadziła szczegółową meliorację zbioru dokumentów pergaminowych, wydzielając 26 dokumentów z księgi akcesyjnej rękopisów oraz wpisała do nowo założonej księgi inwentarzowej dokumentów pergaminowych 633 jednostki. Ponadto założyła księgę inwentarzową muzealiów, do której wpisała 91 obiektów, m.in. zbiór luźnych pieczęci, medale i odznaczenia. Równocześnie zdecydowano o zamknięciu dotychczasowej księgi akcesyjno-inwentarzowej rękopisów i założeniu od 2019 r. dwóch odrębnych ksiąg: akcesyjnej - do rejestracji nowych nabytków i inwentarzowej - do ewidencji opracowanego zasobu rękopiśmiennego.

Od maja 2018 r. rozpoczęto katalogowanie rękopisów w bazie KRAK 8. W oparciu o instrukcję opracowaną przez K. Sanetrę opracowano wewnętrzne zasady katalogowania elektronicznego rękopisów (J. Czapla). Wprowadzono do bazy 625 rekordów bibliograficznych i 841 rekordów egzemplarza, co stanowi około 5\% zasobu (B. Korniak, E. Knapek, M. Radziszewska, E. Danowska). Nadzór nad poprawnością wprowadzanych do bazy KRAK 8 danych sprawowała Julia Czapla. 
Systematycznie prowadzono dokumentację dotyczącą czytelników (202 ankiety stanowiące podstawę udostępniania). W ramach wypożyczeń międzybibliotecznych wysłano 82 szpule mikrofilmów do 13 instytucji, a na potrzeby czytelników sprowadzono 2 szpule (E. Knapek).

Kontynuowano archiwizację zbiorów na dyskach wymiennych. W roku 2018 zdigitalizowano w ten sposób 18 jedn. rękopisów. Przygotowano materiały do 12 wystaw organizowanych przez placówki muzealne. Opracowano 52 kwerendy pisemne. Przekazano do konserwacji 3 dokumenty pergaminowe.

W związku ze zgłaszanymi w 2017 r. przez ówczesnego kierownika Działu J.M. Dziewulską podejrzeniami o gwałtowny wzrost zagrożenia mikrobiologicznego w magazynie rękopisów przeprowadzono badania mikrobiologiczne środowiska i zasobów magazynu. Ekspertyzę wykonał dr Tomasz Sawoszczuk z Katedry Mikrobiologii UE, który stwierdził, że „stężenie bakterii [...] nie przekracza wartości wyznaczonych dla innych bibliotek w kraju”.

Prowadzono prace porządkowe w magazynie, przed przeniesieniem na II piętro mapniki zostały opróżnione, mapy zapakowane i przeniesione na teren Gabinetu Rycin (E. Knapek, Ł. Łukawski). Również dokumenty pergaminowe i inkunabuły zostały zdeponowane w magazynie Gabinetu Rycin (M. Gawłowski). W magazynie przeprawiano rękopisy i dokumenty pergaminowe w nowe tektury i teczki bezkwasowe (50 jedn., M. Gawłowski).

\section{Stare druki}

W 2018 roku zakończono remont magazynu starych druków i kartografii na II piętrze budynku. Wykonano nowe oświetlenie, zdemontowano i usunięto zniszczone, ponad 50-letnie regały, zamontowano komplet nowych regałów metalowych o wymiarach dostosowanych do przechowywanych na nich starych druków i atlasów, zamontowano nowe mapniki formatu A0, przeniesiono z III piętra mapniki formatu A1. Od października przystąpiono do rozpakowywania i rozlokowywania zbiorów. Do 14 XII ustawiono na półkach ponad 12020 jednostek starych druków (J. Czapla, Ł. Łukawski, A. Łakomski, B. Panek) oraz cały księgozbiór kartograficzny (M. Gawłowski). W przyszłym roku rozpakowane zostaną mapy i pozostały zbiór starych druków.

Opracowaniem komputerowym objęto stare druki w kolejności zapisów inwentarzowych (J. Czapla, Ł. Łukawski - od 1 VIII 2018).

Do bazy NUKAT wprowadzono:

- 743 rekordy bibliograficzne

- 71 rekordów zmodyfikowanych

- 521 rekordów haseł wzorcowych

- zmodyfikowano 42 rekordy haseł wzorcowych.

Do bazy KRAK 8:

- skopiowano z NUKAT- u 384 rekordy

- utworzono 1248 rekordów egzemplarza

- utworzono 8 rekordów zasobu.

Tym samym w katalogu komputerowym figuruje obecnie 8938 starodruków, tj. ok. 56\% zbiorów starych druków naszej Biblioteki.

Skatalogowano 161 dzieł w 84 wol. metodą tradycyjną (J. Czapla). Wśród nich były m.in. pozycje pochodzące z daru M. Kruszyńskiego, ze starego zasobu oraz z rozpisania klocków introligatorskich. Melioracji poddano 1123 dzieła (J. Wojtowicz, J. Czapla), do katalogów napisano 3792 karty (J. Wojtowicz).

Systematycznie prowadzono dokumentację dotyczącą czytelników (10 ankiet stanowiących podstawę udostępniania). Czytelnikom udostępniono 63 stare druki. Opracowano 22 kwerendy pisemne, w tym 2 zagraniczne. 


\section{Kartografia}

W 2018 r. cały zbiór kartograficzny został przeniesiony do wyposażonego w nowe regały magazynu na II piętrze. Do 14 XII ustawiono na półkach cały księgozbiór kartograficzny (M. Gawłowski). W przyszłym roku rozpakowane zostaną mapy.

Nad całością prac zabezpieczających czuwały E. Knapek i J. Czapla. Z powodu prac związanych z pakowaniem i przenoszeniem, zbiór nie był udostępniany. Dodatkowo z uwagi na vacat w 2018 roku nie prowadzono żadnych prac katalogowych.

\section{Druki ulotne}

Z uwagi na wieloletni vacat, i remont magazynu, nie prowadzono żadnych działań związanych z opracowywaniem tego zespołu.

W Dziale przeprowadzono 15 pokazów rękopisów i starych druków.

Zorganizowano pokaz sprzętu i zastosowania technik rejestracji wielomianowych map tekstury i obrazowania hiperspektralnego, prowadzony przez dr. hab. T. Łojewskiego z Wydziału Inżynierii Materiałowej i Ceramicznej AGH w ramach programu E-RIHIS.PL (E. Knapek).

Zob. też: Dział XIII (skontrum), XIV (działalność dydaktyczna), XVIII (odczyty, konferencje), XIX (działalność wydawnicza), XX (konserwacja), XXI (wykaz prac drukowanych).

\section{GABINET RYCIN}

Kontynuowano rozpisywanie albumów na poszczególne ryciny, opracowano albumy: 313 (74 ryciny M. Adamska), 384-386 (319 rycin J. Motyka). W sumie skatalogowano w ten sposób 393 ryciny.

Baza wydawnictw zwartych BOOK zawiera obecnie 7074 książki w 7742 wol., a baza czasopism około 200 tytułów w 5535 wol. (K. Krużel). Łącznie księgozbiór Gabinetu liczy obecnie 13277 woluminów.

W dalszym ciągu opracowywano ujednolicone formy opisu rycin w programie ISIS, przeprowadzono poprawę znaków literowych, skupiając się na literach niemieckich, źle odtworzonych przez system podczas konwersji z MS DOS do Windows. Przegląd i ewentualna poprawa objęła ponad 6700 rycin szkoły niemieckiej i szwajcarskiej. Łącznie z nowymi nabytkami i uzupełnieniami baza powiększyła się o 571 opisów i wykazuje obecnie 43583 rekordy, notując mniej lub bardziej szczegółowo cały zasób grafik Gabinetu Rycin PAU (K. Krużel). Kontynuowano zabezpieczanie rycin papierem bezkwasowym i usuwanie kwaśnych opraw. Przegląd objął kasety od A do L w szkole niderlandzkiej, łącznie 3546 rycin. W magazynie wydzielono także miejsce na przyrastające grafiki współczesne.

Drukiem ukazała się druga część piątego tomu Katalogu rycin Gabinetu Rycin PAU...: Rodzina Galle: Theodoor, Cornelis I..., opracowany przez M. Pokorską-Primus, z indeksami filigranów, proweniencji i ikonograficznym wykonanymi przez K. Krużla. Do X tomu Katalogu rycin Gabinetu Rycin PAU...: Laan-Leyden M. Adamska opracowała ryciny Lucasa van Leydena, a J. Motyka ukończył indeks filigranów. Anna Olszewska kontynuowała prace nad katalogiem akwafort Vaclava Hollara (461 rycin) oraz prace nad metodami komputerowej analizy obrazu, celem stworzenia aplikacji umożliwiającej automatyczne porównywanie znaków wodnych (we współpracy z dr Joanną Gancarczyk z ATH i mgr. Marcinem Dzierżakiem z AGH).

W kolejnym darze od prof. Krzysztofa Skórczewskiego otrzymano 38 miedziorytów. Swoje prace przekazały też panie Alina Kalczyńska i Ewa Zawadzka. Z daru Mirosława Kruszyńskiego wpłynęły do zbiorów portrety z XVII i XVIII wieku oraz ryciny przyrodnicze. Kolekcję rycin współczesnych uzupełniły dary Jana Motyki i Elżbiety Orman.

Dopisano do inwentarza 117 rycin, pozostałe 20 miedziorytów, otrzymanych w darze od prof. K. Skórczewskiego w drugiej połowie grudnia 2018 r., zostanie wpisanych do inwentarza 
w 2019 r. Inwentarz rycin luźnych obejmuje obecnie numery 1-15 000 i 25 001-38 809. Dział albumów wzbogacił się o dwa wydawnictwa zagraniczne zawierające 300 rycin i trzy polskie z 59 rycinami. Tym samym liczba rycin w zbiorach wzrosła do 99181.

Zbiór rysunków powiększył się o jedną pozycję i wynosi obecnie 2266 pozycji.

Zbiór ekslibrisów obejmuje 11198 pozycji w inwentarzu. Wraz z dubletami zbiór liczy obecnie 14639 pozycji.

Czytelnikom udostępniono 119 pozycji z księgozbioru podręcznego. Przeprowadzono 42 kwerendy, w tym 11 zagranicznych. Łącznie udostępniono 6759 rycin i fotografii dawnych. Kwerendy dotyczyły szeroko pojętej twórczości Leonarda da Vinci, historii Eneasza, widoków, wzorów graficznych do odnawianych dzieł. Pozostałe kwerendy miały charakter przeglądowy i odnosiły się do rozmaitych dzieł pod względem szkół graficznych i okresu pochodzenia.

Ponadto przeprowadzono wyceny grafik wypożyczanych na wystawy (K. Krużel).

Korzystającymi byli m. in. historycy sztuki (27), kolekcjonerzy grafik (5), konserwatorzy (3), antykwariusz, teatrolog, administracja PAU.

W 2018 r. ryciny z naszych zbiorów, łącznie 141, prezentowane były na 3 wystawach.

Na wystawie Seria oryginalnych grafik artystów polskich w opracowaniu Aliny Kalczyńskiej w Archiwum Nauki PAN i PAU w Krakowie, odbywającej się w maju i czerwcu br., zaprezentowano 116 miniatur graficznych i ekslibrisy. Kuratorem wystawy Seria oryginalnych grafik artystów... i książki pod tymże tytułem był Jan Motyka.

Anna Olszewska wraz ze Scottem Simpsonem (Uniwersytet Jagielloński) przygotowała wystawę o przetworzeniach wyobrażeń bóstw słowiańskich w ramach cyklu Kobieta, Wiedza, Władza. Wystawa pod tytułem Apokryfy słowiańskie, prezentująca ryciny, starodruki i figury z brązu, została otwarta 29 listopada w Muzeum Archeologicznym w Krakowie, w połączeniu z sesją naukową pod patronatem PAN. Na wystawie zaprezentowano m.in. 23 ryciny z dwóch wydawnictw wypożyczonych z Gabinetu Rycin. Dwie ryciny wypożyczono do Muzeum Narodowego we Wrocławiu na wystawę Manieryzm wrocławski, odbywającą się od 27 lutego do 13 maja.

Zob. Dział XIV (działalność dydaktyczna), XVI (wystawy i pokazy), XVII (podnoszenie kwalifikacji, szkolenia), XVIII (odczyty), XXI (wykaz prac drukowanych).

\section{PRACOWNIA REPROGRAFICZNA}

Pracownia realizowała zamówienia na kopie elektroniczne. Zrealizowano 111 zamówień, w tym: 50 dla instytucji naukowych, 41 dla osób prywatnych, 8 zagranicznych i 12 na potrzeby Biblioteki. Wykonano 404 fotografie cyfrowe oraz 11749 skanów. Realizowane prace zarejestrowano na 22 płytach CD-R, 11 płytach DVD i 10 pendrivach, 68 zamówień wysłano pocztą mailową. Wykonano również 3824 skany z mikrofilmu.

W ramach digitalizacji zbiorów specjalnych przekazano do działu kopie cyfrowe 23 jedn. inw. rękopisów i pergaminów.

Mgr Jakub Chojnacki był autorem zdjęć w wydawnictwach własnych Biblioteki (Rocznik Biblioteki..., Katalog rycin: Laan-Leyden) oraz wykonał fotografie rycin na wystawę Seria oryginalnych grafik artystów...

\section{SKONTRUM}

W 2017 roku skontrum nieustające zbiorów zostało zawieszone z uwagi na remont magazynu głównego. Dalsze prace będą prowadzone po zakończeniu remontu. 
Równocześnie Dział Opracowania Druków prowadzi prace przy retrokonwersji zawartości pierwszych dwóch tomów inwentarzy, wykonując tym samym powtórne skontrum wydawnictw ciągłych w zakresie sygnatur od 1 do 5000 i zwartych od 10001 do 15000 .

W 2018 r. skontrum objęło sygn. 1396 III-1510 I, tj. 170 sygn. w 2704 wol. wyd. ciągłych oraz sygn. 11401 II-12 900 II i 14801 IV-15 000 IV, tj. 800 sygn. w 1770 wol. wyd. zwartych, wśród których odnaleziono współoprawne stare druki i XIX-wieczne nieskatalogowane dotychczas pozycje. W Dziale Zbiorów Specjalnych skontrum połączono z licznymi przesunięciami zbiorów w obrębie pokoi oraz do innych księgozbiorów podręcznych, przesygnowując przy tym 293 wol. (B. Korniak, E. Knapek).

Skontrum księgozbioru podręcznego w Czytelni Głównej objęło 1057 pozycji w 5157 wol. (M. Urgacz, P. Świątczak, B. Stempin).

Całością prac inwentaryzacyjnych zbiorów kieruje wicedyrektor Biblioteki M. Kremer.

\section{DZIAŁALNOŚĆ DYDAKTYCZNA I ORGANIZACYJNA}

Opracowano 197 szczegółowych kwerend odnoszących się do zasobu rycin, rękopisów, starych druków i map, a mianowicie: z zakresu grafiki 42 (w tym 11 zagranicznych), 52 (w tym 2 zagraniczne) z zakresu rękopisów, 22 (w tym 2 zagraniczne) z zakresu starych druków. W Dziale Udostępniania Zbiorów wykonano 81 kwerend pisemnych.

W Czytelni Działu Zbiorów Specjalnych przygotowano 16 pokazów rękopisów i starych druków, a także 6 pokazów rycin. Poszczególne grupy zapoznawano również z pracą Czytelni Głównej. Pokazy organizowane były m.in. dla: studentów Instytutu Historii Sztuki i Instytutu Historii Uniwersytetu Jagiellońskiego, Uniwersytetu Pedagogicznego w Krakowie, Uniwersytetu Kazimierza Wielkiego w Bydgoszczy, Wydziału Humanistycznego AGH, Krajowego Funduszu na rzecz Dzieci.

Specjalny pokaz odbył się dla uczestników XXVI Zjazdu International Advisory Committee of Keepers of Public Collection of Graphic Art ze Stanów Zjednoczonych (K. Krużel, A. Olszewska). Pokazy przygotowywali i prowadzili pracownicy Działu Zbiorów Specjalnych, Gabinetu Rycin, Działu Udostępniania i Działu Gromadzenia Zbiorów: M. Adamska, J. Czapla, E. Danowska, E. Knapek, A. Olszewska oraz W. Lipowski, B. Stempin, P. Świątczak.

Zorganizowano również warsztaty stosowania technik badania światłoczułości atramentu i rejestracji wielowymiarowych map tekstury piętnastowiecznej oprawy kodeksów, w ramach współpracy z dr. hab. Tomaszem Łojewskim z AGH w ramach programu E-RHIS (E. Knapek).

Dr Anna Ols zew ska prowadziła konwersatoria, ćwiczenia i seminarium magisterskie na Wydziale Humanistycznym Akademii Górniczo-Hutniczej.

Mgr Joanna D ziewulsk a prowadziła zajęcia dla studentów historii sztuki UJ o specjalności ochrona dóbr kultury.

Pracownicy Biblioteki brali również udział w grantach:

Dr Elżbieta Knape k:

- Badania Kancjonału Wawrzyńca z Giesek ze zbiorów Biblioteki Naukowej PAU i PAN w Krakowie - kierownik projektu,

- Corpus Academicum Cracoviense. Elektroniczna baza studentów i profesorów Uniwersytetu Krakowskiego w okresie staropolskim 1364-1780.

Mgr Lucyna Pyrzow ska

- Opracowanie katalogów XIX-wiecznych druków wydanych na emigracji i ziemiach polskich ze zbiorów Biblioteki Polskiej w Paryżu i Towarzystwa Historyczno- Literackiego.

W Działach: Opracowania Druków i Gromadzenia Zbiorów prowadzono szkolenia dla pracowników Biblioteki. 
Dr hab. Ewa Danowska uzyskała uprawnienia biegłego sądowego Sądu Okręgowego w Krakowie w zakresie ekspertyzy oryginalności dokumentów rękopiśmiennych i map do 1945 r., ocena $i$ wycena wartości rynkowej...

Dr Wojciech Lipowski sprawował opiekę redakcyjną nad stroną internetową Biblioteki, kontynuował współpracę z platformą Portal Czasopism Naukowych Uniwersytetu Jagiellońskiego w zakresie prac dotyczących elektronicznej wersji Rocznika Biblioteki Naukowej PAU i PAN, zajmował się także organizacją pokazów dla studentów.

Julia Czapla prowadziła we współpracy z K. Grodziską profil Biblioteki w serwisie Facebook (odnotowano 643 użytkowników, posty miały 2913 polubień i 148 udostępnień).

\section{WSPÓŁPRACA Z INNYMI BIBLIOTEKAMI, INSTYTUCJAMI, ORGANIZACJAMI I WYDAWNICTWAMI}

Współpraca z krakowskimi bibliotekami naukowymi przebiegała na tych samych zasadach, co w latach ubiegłych. W ramach Krakowskiego Zespołu Bibliotecznego kontynuowano współdziałanie z bibliotekami krakowskich uczelni, zwłaszcza w zakresie prac prowadzonych w obrębie bazy KRAK 8. Mgr Monika Fiutowska zarządzała bazą KRAK 8 jako bibliotekarz systemowy, a podczas jej nieobecności była zastępowana przez mgr Kamilę Woźniak. Wymianę wydawnictw prowadzono z 480 bibliotekami w 62 krajach i z 132 instytucjami w Polsce.

Dr Karolina Grodzis ka wchodziła w skład Rady Dyrektorów Porozumienia o Współpracy Bibliotek Wdrażających i Użytkujących VTLS. Jako członek Rady PAU uczestniczyła w jej comiesięcznych spotkaniach. Była członkiem Rady Naukowej Biblioteki Międzynarodowego Centrum Kultury w Krakowie, Rady Muzeum Regionalnego im. dr Janusza Petera w Tomaszowie Lubelskim oraz Rady Naukowej Rocznika Biblioteki Kraków. Uczestniczyła w pracach jury konkursu na Krakowską Książkę Miesiąca, obradującego w siedzibie Biblioteki Kraków. Była członkiem Rady Programowej kwartalnika Cracovia Leopolis, wydawanego przez krakowski oddział Towarzystwa Miłośników Lwowa i Kresów Południowo-Wschodnich. Za współpracę z władzami miasta Gdańska i Klubu Sportowego Lechia została uhonorowana medalem Prezydenta Miasta Gdańska „Ubi concordia ibi victoria".

Dr Karolina Grodziska była członkiem Zespołu Redakcyjnego Rocznika Biblioteki Naukowej PAU i PAN w Krakowie, w skład którego wchodziła też dr hab. Ewa D a now s ka, mgr Joanna M. D zi ewulska, dr Elżbieta Knapek, dr Wojciech Li pow ski, dr Anna Olszew ska.

Mgr Krzysztof Krużel i dr Anna Olszewska byli członkami Międzynarodowego Stowarzyszenia Kustoszy Sztuki Holenderskiej i Flamandzkiej CODART (Council for curators of Dutch and Flemish art).

Mgr Jan Moty k a był jurorem konkursu na Najlepszą Grafikę Miesiąca przy Krakowskim Oddziale ZPAP.

Dr hab. Ewa Danow sk a podczas II Światowego Zjazdu Radłowian otrzymała statuetkę ambasadora miasta i gminy Radłów.

W ramach wieloletniej współpracy z Biblioteką Narodową kontynuowano dostęp do bazy ACADEMICA.

Zeskanowane rękopisy Oskara Kolberga, przechowywane w naszej Bibliotece, od 2015 roku są dostępne na stronie internetowej Instytutu im. Oskara Kolberga w Poznaniu.

Do Rady Naukowej Biblioteki, oprócz dyrektora i wicedyrektora, wchodzili: dr hab. Ewa Da now ska (sekretarz Rady) i mgr Krzysztof Krużel.

Dr Elżbieta Knapek i mgr Julia C zap la wzięły udział w nagraniu programu telewizyjnego (3 VIII) poświęconego dziejom i zbiorom PAU, a dr hab. Ewa Danowska udzieliła wywiadu telewizji kablowej (4 II) w Poznaniu na temat albumu Teofila Lenartowicza i jego związków z Wielko- 
polską. Telewizja Polska Oddział w Krakowie filmowała pomieszczenia czytelni do filmu dokumentalnego „Iskra Niepodległości”.

\section{WYSTAWY I POKAZY}

Zbiory Biblioteki w 2018 roku prezentowano na 18 wystawach.

Zbiory rycin pokazano na 3 wystawach (łącznie udostępniono 141 rycin):

- 27 II 2018 - 13 V 2018, Manieryzm wrocławski, Muzeum Narodowe, Wrocław

- 9 V 2018 - 4 VI 2018, Seria oryginalnych grafik artystów polskich w opracowaniu Aliny Kalczyńskiej 1984-2014, Archiwum Nauki PAN i PAU w Krakowie, Biblioteka Naukowa PAU i PAN, Kraków, kurator mgr Jan Motyka

- 30 XI 2018 - 30 III 2019, Apokryfy Stowiańskie, Muzeum Archeologiczne w Krakowie, Kraków, kurator dr Anna Olszewska.

Rękopisy i książki prezentowano na 15 wystawach:

- 22 VI 2017 - 11 II 2018, Kobiece spojrzenie. O aktorstwie Antoniny Hoffmanowej, Muzeum Historyczne Miasta Krakowa, Kraków

- 9 XI 2017 - 30 III 2018, Z myśla o przyszłości nauki i Ojczyzny. Ofiarodawstwo na rzecz PAU, Archiwum Nauki PAN i PAU, Kraków

- 1 XII 2017 - 8 IV 2018, Lwów, 24 czerwca 1937. Miasto, architektura, modernizm, Międzynarodowe Centrum Kultury, Kraków

- 17 XII 2017 - 18 II 2018, Seweryn Mielżyński (1804-1872), Muzeum Narodowe w Poznaniu

- II 2018 - VII 2018, Bronisław Pitsudski 1866-1918, Muzeum Historii Miasta Mińska i Muzeum Tatrzańskie, Zakopane - Mińsk - reprodukcje fotografii

- III 2018 - VI 2018, Cesi a Cechy polskymi ocima v 19 stoleti, Instytut Masaryka i Archiwum Akademii Nauk Republiki Czeskiej we współpracy z Archiwum Nauki PAN i PAU w ramach projektu Wymiana inspiracji $i$ wiedzy $w$ kontaktach czeskich i polskich uczonych, Praha skany obiektów

- 28 III 2018 - 30 VI 2018, Zaczęło się w Krakowie..., Biblioteka Główna AGH, Kraków

- 20 IV 2018 - 10 VI 2018, Matejko, wystawa dzieł Jana Matejki, Muzeum Regionalne w Stalowej Woli

- 25 V 2018 - 24 VI 2018, Miesiąc Fotografii w Krakowie, Fundacja Sztuk Wizualnych

- 8-20 V 2018, Wincenty Kadtubek i jego Kronika, Miejsko-Gminna Biblioteka Publiczna w Jędrzejowie

- 11 V 2018 - 19 VIII 2018, Cricot idzie!, Ośrodek Dokumentacji Sztuki T. Kantora CRICOTEKA, Kraków

- 17 X 2018 - 20 I 2019, Ajnowie, Górale i Bronisław Pitsudski, Muzeum Sztuki i Techniki Japońskiej Manggha, Kraków

- 15 X 2018 - 15 XI 2018, Adam Mickiewicz w Krakowie, Biblioteka Kraków oraz Collegium Maius UJ, Kraków

- 15 XI 2018 - 3 XII 2018, Opis żup bocheńskich i wielickich, Muzeum Żup Krakowskich, Wieliczka,

- 16 XI 2018 - 15 III 2019, Niepodległej, 100. Rocznica odzyskania niepodległości..., Archiwum Nauki PAN i PAU, Kraków. 


\section{PODNOSZENIE KWALIFIKACJI, SZKOLENIA}

Szkolenie wszystkich pracowników dotyczące bezpieczeństwa przeciwpożarowego w związku z wprowadzeniem nowej instrukcji przeciwpożarowej.

Szkolenie pracowników wszystkich działów w korzystaniu z komputerowego modułu obsługi czytelnika (elektronicznego systemu wypożyczania).

Mgr Magdalena A da m ska

- udział w 3. warsztacie informacyjnym oferty MOLAB/FIXLAB organizowanym przez Polskie Konsorcjum dla Badań nad Dziedzictwem Kulturowym E-RIHS.PL, ASP, Kraków, 12 VI 2018.

Mgr Julia Czap la

- udział w 3. warsztacie informacyjnym oferty MOLAB/FIXLAB organizowanym przez Polskie Konsorcjum dla Badań nad Dziedzictwem Kulturowym E-RIHS.PL, ASP, Kraków, 12 VI 2018.

Mgr Anna Dusza-Bielenin

- udział w spotkaniu bibliotekarzy w ramach Polskiej Grupy Użytkowników VTLS/VIRTUA, Biblioteka Główna Uniwersytetu Pedagogicznego, Kraków, 14-15 VI 2018.

Dr Elżbieta Kn a p ek

- udział w pokazie sprzętu i zastosowania technik rejestracji wielomianowych map tekstury i obrazowania hiperspektralnego, prowadzonym przez dr. hab. T. Łojewskiego z Wydziału Inżynierii Materiałowej i Ceramicznej AGH, Biblioteka Naukowa PAU i PAN, Kraków 9 V 2018

- udział w 3. warsztacie informacyjnym oferty MOLAB/FIXLAB, organizowanym przez Polskie Konsorcjum dla Badań nad Dziedzictwem Kulturowym E-RIHS.PL, ASP, Kraków, 12 VI 2018.

Mgr Aneta Kołodziejczyk

- studia niestacjonarne II stopnia, kierunek ekonomia, specjalność rachunkowość i zarządzanie finansami na Wydziale Zarządzania i Komunikacji Społecznej UJ.

Mgr Krzysztof Kruże 1

- udział w pokazie sprzętu i zastosowania technik rejestracji wielomianowych map tekstury i obrazowania hiperspektralnego, prowadzonym przez dr. hab. T. Łojewskiego z Wydziału Inżynierii Materiałowej i Ceramicznej AGH, Biblioteka Naukowa PAU i PAN, Kraków 9 V 2018.

Mgr Urszula Orłow s ka - W ęgi e 1

- ukończenie studiów podyplomowych z zakresu bibliotekoznawstwa i informacji naukowej, Uniwersytet Pedagogiczny.

Mgr Maria Radziszew ska

- ukończenie studiów podyplomowych w zakresie edytorstwa na Wydziale Polonistyki UJ.

Mgr Bartłomiej Ste mpin

- studia III stopnia na Wydziale Studiów Międzynarodowych i Politycznych UJ. 
Mgr Piotr Św iątc zak

- studia III stopnia na Wydziale Zarządzania i Komunikacji Społecznej UJ

- studia podyplomowe Dawna książka, zbiory specjalne i archiwalia na Wydziale Zarządzania i Komunikacji Społecznej UJ.

Mgr Małgorzata Turczak

- spotkanie bibliotekarzy w ramach Polskiej Grupy Użytkowników VTLS/VIRTUA, Biblioteka Główna Uniwersytetu Pedagogicznego, Kraków, 14-15 VI 2018.

Mgr Maria Urgac z

- ukończenie studiów podyplomowych z zakresu bibliotekoznawstwa i informacji naukowej, Uniwersytet Pedagogiczny.

Mgr Kamila Woźniak

- spotkanie bibliotekarzy, w ramach Polskiej Grupy Użytkowników VTLS/VIRTUA, Biblioteka Główna Uniwersytetu Pedagogicznego, Kraków, 14-15 VI 2018.

\section{ODCZYTY, KONFERENCJE, STYPENDIA I WYJAZDY}

Mgr Magdalena A d a m sk a

- udział w konferencji naukowej Bona Sforza d'Aragona (1494-1557). Legenda i rzeczywistość, Zamek Królewski, Warszawa, 20-21 VI 2018

- udział w międzynarodowej konferencji Multiplied ane modified. Reception of the prited image in the fifteenth and sixteenth centuries, Uniwersytet Warszawski, Muzeum Narodowe, Warszawa, 28-29 VI 2018

- kwerenda dotycząca zbioru rycin Lucasa van Leydena, Muzeum Narodowe, Warszawa, 19-21 IV 2018

- kwerenda dotycząca zbioru rycin Lucasa van Leydena, Muzeum Narodowe, Kraków, 17 XII 2018

- zwiedzanie wystawy Manieryzm wrocławski, Muzeum Narodowe, Wrocław, 10-11 V 2018

- udział w IV European Congress on Jewellery $\mathrm{z}$ referatem Peapod style in the Jewellery of the 17th century Polish-Lithuanian Commonwealth, Universidade Catolica Portuguesa, Porto, 28-29 XI 2018.

Mgr Julia Czap la

- udział w konferencji „,...jak pies...”. O psie w literaturze, kulturze i języku z referatem Psy w kręgu zainteresowania encyklopedystów francuskich, Instytut Kultury Regionalnej i Badań Literackich, Siedlce, 6-7 VI 2018

- udział w konferencji Libri Rariores \& Rarissimi. Polonica w zbiorach państwowych bibliotek Rosji, Ukrainy, Białorusi i Litwy, Centrum Badawcze Bibliografii Polskiej Estreicherów, Kraków, 27 II - 1 III 2018

- udział w spotkaniu konsultacyjnym Przemiany Polony w ramach projektu e-ustuga OMNIS, Biblioteka Narodowa, Warszawa, 22 III 2018

- udział w Targach Dziedzictwo: Zabezpieczenie dziedzictwa dla przyszłych pokoleń, klasztor oo. franciszkanów, Kraków, 11-12 X 2018.

Dr hab. Ewa Danowska

- udział w V ogólnopolskiej konferencji naukowej Niewygodne dla władzy. Ograniczanie wolności stowa z referatem Konstanty Majeranowski - najstynniejszy cenzor Wolnego Miasta Krakowa, Torun 18-19 X 2018 
- udział w konferencji 100 lat LO im. kard. S. Wyszyńskiego w świetle setnej rocznicy odzyskania Niepodległości z referatem Liceum Krzemienieckie w odrodzonej Polsce (1920-1939), Staszów, 7 IV 2018

- udział w konferencji Oświecone nieoświecone. Tradycja, tożsamość, inność z referatem Jak Tadeusz Czacki w trosce o demokrację walczył z Konstytucją 3 Maja, Wrocław, 28-29 XI 2018

- udział w konferencji Polityka w prasie kobiecej z referatem Polityka na lamach prasy kobiecej w Galicji 1900-1918, Uniwersytet w Białymstoku, Białystok, 25-27 V 2018

- udział w konferencji Polscy Ormianie w drodze do niepodległej, z referatem Wiadomości o polskich Ormianach ze zbiorów rękopiśmiennych Biblioteki Naukowej PAU i PAN w Krakowie, Biblioteka Kraków oraz Urząd Miasta Krakowa, Kraków, 9-10 X 2018

- udział w konferencji Seweryn Mielżyński (1804-1872) z komunikatem Wielkopolanie z kręgu Seweryna Mielżyńskiego w albumie „Umarli żywi” Teofila Lenartowicza, Muzeum Narodowe, Poznań, 16 II 2018

- wykład Historia pewnego albumu. Teofil Lenartowicz „Umarli żywi”, Muzeum Narodowe, Poznań, 4 II 2018

- wykład Wokót pamiętników Emanuela Hohenauera de Charleza. Wojna światowa 1914-1918, XX Małopolskie Dni Dziedzictwa Kulturowego, Fort Barycz, Kraków, 19 V 2018

- wystąpienie na posiedzeniu Komisji Historii Wojen i Wojskowości PAU z prezentacją opracowania wspomnień gen. E. Hohenauera z lat 1914-1918.

Dr Karolina Grodzis k a

- odczyt Zapomniani lwowscy dziennikarze: Jan Zahradnik i Michalina Grekowicz-Hausnerowa, Koło Lwowian, Klub pod Gruszką, Kraków, 6 II 2018

- udział w konferencji Biblioteka w czasach przełomu, Biblioteka Kraków, Urząd Miasta Krakowa, Kraków, 19 I 2018

- udział w konferencji Roman Ingarden and His Times. An International Phenomenological Conference 2018, z prezentacją Korespondencja E. Husserla do R. Ingardena przechowywana w zbiorach Biblioteki Naukowej PAU i PAN w Krakowie, Kraków, 27 X 2018

- konferencja z okazji 30 rocznicy utworzenia Towarzystwa Kultury Polskiej Ziemi Lwowskiej zatytułowana: Lwów w historii i kulturze polskiej, referat Pomiędzy Lwowem a Krakowem. Janina Reihert-Toth i jej twórczość rzeźbiarska, referat wygłosił dr Stanisław Dziedzic, Lwów, 19 X 2018

- udział w spotkaniu Polskiej Grupy Użytkowników VTLS/VIRTUA, Uniwersytet Pedagogiczny - Biblioteka Główna, Kraków, 14-15 VI 2018

- udział w cyklicznych spotkaniach Krakowskiego Zespołu Bibliotecznego, Biblioteka Główna AGH, Kraków, 26 III, 13 IV, 22 VI 2018 oraz Biblioteka Główna Uniwersytetu Pedagogicznego, Kraków 20 IX, 28 IX, 30 XI 2018

- udział w promocji książki Ojczyźnie naszej, Polsce, bądźmy wierni, Bitwa miechowska 17 lutego1863 r. w relacjach uczestników..., Powiatowa i Miejska Biblioteka Publiczna im. Marii Fihel w Miechowie, Miechów, 17 II 2018

- udział w sesji ogólnej zgromadzenia Oddziału PAN w Krakowie, Kraków, 8 VI 2018

- udział w posiedzeniu Rady Naukowej Biblioteki Międzynarodowego Centrum Kultury, Kraków, 9 XI 2018

- udział w posiedzeniu Rady Naukowej Muzeum Regionalnego im. J. Petera, Tomaszów Lubelski, 14 V 2018

- udział w uroczystości wręczenia Nagród Miasta Krakowa, Urząd Miasta, Kraków, 19 X 2018 (wśród laureatów prof. dr hab. Stanisław Grodziski). 


\section{Dr Elżbieta Knapek}

- udział w spotkaniach Proweniencyjnej Grupy Roboczej, Ossolineum, Wrocław, 31 I 2018 i 12 X 2018

- udział w Forum Sfragistycznym z referatem Dwojakie zastosowanie tłoków pieczętnych w funkcji pierwotnej i wtórnej, Ciążeń, 22-26 VI 2018.

Mgr Krzysztof Kruże 1

- udział w XXVI Zjeździe International Advisory Committee of Keepers of Public Collections of Graphic Art, Warszawa, 4-7 VI 2018

- udział w sympozjum naukowym jubileuszu 200 lat Gabinetu Rycin - z historia w przyszlość z prezentacją Historia i problemy tworzenia bazy PAU-art w Polskiej Akademii Umiejętności, Biblioteka Uniwersytecka, Warszawa, 5 XII 2018.

Dr Wojciech Lipowski

- udział w posiedzeniu naukowym Wydziału Filologicznego PAU z wykładem nt. literatury współczesnej Sztuka widzenia i pisania Kornela Filipowicza $w$ wybranych kontekstach historycznoliterackich, PAU, Kraków, 14 VI 2018.

Mgr Jan Motyka

- kwerenda bibliograficzna dotycząca pracy nad X tomem Katalogu rycin..., Praga, 25-26 IX 2018.

Dr Anna Olszew ska

- udział w konferencji EVA London. Electronic Visualisation and the Arts, BCS, Londyn, 9-13 VII 2018.

Mgr Urszula Orłow ska - W ę g i e 1

- udział w posiedzeniu naukowym Wydziału Filologicznego PAU, Kraków, 14 VI 2018.

Mgr Lucyna Py rzow ska

- udział w konferencji Druki XIX wieku w nadsekwańskiej Ksiażnicy Narodowej, z referatem Jan Tysiewicz i egzemplarze „Konrada Wallenroda” i , Grażyny” w Bibliotece Polskiej w Paryżu, Polska Akademia Umiejętności, Kraków, 10-11 V 2018

- udział w konferencji Druki XIX wieku w nadsekwańskiej Książnicy Narodowej, z wystąpieniem Sprawozdanie z wykonania projektu badawczego Polskiej Akademii Umiejętności dotyczacego opracowania katalogów XIX wiecznych druków wydanych na emigracji i ziemiach polskich w zbiorach Biblioteki Polskiej i Towarzystwa Historyczno-Literackiego w Paryżu, Polska Akademia Umiejętności, Kraków, 10-11 V 2018.

Mgr Bartłomiej S te mpin

- udział w ogólnopolskiej konferencji naukowej Groza i lęk w kulturze z referatem Fantastyka, groza, panestetyzm i antyestetyzm w poglądach i twórczości Howarda Phillipsa Lovecrafta, Uniwersytet Łódzki, Łódź, 7-8 XII 2018.

Mgr Piotr Ś wi ąt c zak

- udział w konferencji naukowej Rabunek i germanizacja polskich dzieci w czasie II wojny światowej, Centrum Dokumentacji Zsyłek, Wypędzeń i Przesiedleń Uniwersytetu Pedagogicznego, IPN Oddz. Kraków, Kraków, 21 XI 2018

- udział w posiedzeniu Komisji Historii Wojen i Wojskowości PAU, poświęconego Emanuelowi Hohenauerowi, Kraków, 9 I 2018. 


\section{DZIAŁALNOŚĆ WYDAWNICZA}

W omawianym okresie 14 pracowników Biblioteki prowadziło badania naukowe, dokonując edycji źródłowych oraz opracowań katalogowych i publikując własne artykuły i rozprawy. Za najważniejsze dokonania Biblioteki w tym okresie należy uznać publikacje:

- Katalog Gabinetu Rycin PAU w Bibliotece Naukowej PAU i PAN w Krakowie, Szkoła niderlandzka XVI, XVII i XVIII w., część V, 2: Rodzina Galle: Theodoor, Cornelis I, Cornelis II i Cornelis III, Małgorzata Pokorska-Primus, Kraków 2018, ss. 260, tabl. 36

- 63. tom Rocznika Biblioteki Naukowej PAU i PAN w Krakowie, o objętości 29,7 ark. wyd., pod redakcją Karoliny Grodziskiej

- Alina Kalczyńska, Seria oryginalnych grafik artystów polskich w opracowaniu ... 1984-2014, publikacja towarzysząca wystawie ze wstępem Jana Motyki, Kraków 2018, ss. 50

- Kalendarz 2019, Polska Akademia Umiejętności, Biblioteka Naukowa PAU i PAN w Krakowie, z ilustracjami Krzysztofa Skórczewskiego

- J. Łepkowski, Przeglad krakowskich tradycyj, legend, nabożeństw, zwyczajów, przystów $i$ właściwości, reprint ze zbiorów Biblioteki z wstępem K. Grodziskiej, Kraków 2018, ss. IX, 68.

Koszty wydania wszystkich pozycji zostały pokryte ze środków statutowych.

Kompletowano kolejny tom Rocznika... (64), zaplanowany na 2019 rok, przyjmując teksty do teki redakcyjnej i dokonując ich wstępnej kwalifikacji. Równocześnie trwały prace nad kolejnymi tomami katalogów rękopisów i rycin.

W numerze 1. z 2018 r. kwartalnika „Irénikon. Revue des Moines...”, ukazała się pochlebna recenzja dwóch publikacji Biblioteki, tj. Katalogu atlasów XIX w... i Katalogu inkunabułów...

\section{KONSERWACJA ZBIORÓW SPECJALNYCH}

Ze środków statutowych na konserwację wydatkowano 18 186,95 zł. W ramach powyższej kwoty poddano konserwacji 3 dokumenty pergaminowe z XVI I XVII w., dwa z nich to dokumenty cechowe, a jeden to dokument papieski. Oprawiono 33 wol. książek. Oprócz tego poddano konserwacji 4 obiekty ze spuścizny T. Kantora, wypożyczone następnie na wystawę do Ośrodka Dokumentacji Sztuki T. Kantora (na koszt wypożyczającego).

W ramach programu E-RIHIS.PL przeprowadzono badania rękopisu o sygnaturze 1706. Wyniki prac zostały zaprezentowane zarówno w trakcie pokazu sprzętu i zastosowania technik rejestracji wielomianowych map tekstury $i$ obrazowania hiperspektralnego, prowadzonego przez dr. hab. T. Łojewskiego z Wydziału Inżynierii Materiałowej i Ceramicznej AGH w siedzibie PAU, jak też w ramach warsztatów informacyjnych oferty MOLAB/FIXLAB, zorganizowanych w siedzibie Akademii Sztuk Pięknych w Krakowie.

Złożono kolejne wnioski do Ministerstwa Kultury i Dziedzictwa Narodowego na konserwację rękopisów.

\section{WYKAZ PRAC DRUKOWANYCH}

Julia Czapla

- Feles animal est familiare ac domesticus. Przedstawienie kota domowego w kompendiach przyrodniczych XVI w., w: Kot w literaturze, kulturze, języku i mediach, Studies / Animals / Plants SAP tom 1, Siedlce 2018, s. 63-68

- Henryk Bukowski i jego dar. W 130. rocznice ofiarowania, „Rocznik Biblioteki Naukowej PAU i PAN w Krakowie", R. 63: 2018, s. 389-392. 
Ewa Danowska

- Akademia Umiejętności - Polska Akademia Umiejętności. Czas przełomu po odzyskaniu niepodległości, „Rocznik Biblioteki Kraków”, R. 2: 2018, s. 151-173

- Bliscy, którzy odeszli: Józef Odrobina, „Miesięcznik społeczno-kulturalny Kraków” nr 11 (168), listopad 2018, s. 78-79

- Biskup niezwykly - Ludwik Łętowski, „Miesięcznik społeczno-kulturalny Kraków” nr 12 (169), grudzień 2018, s. 64-67

- Dziwactwa Marianny Badeniowej, „Miesięcznik społeczno-kulturalny Kraków” nr 6 (164), czerwiec 2018, s. 76-78

- Edycje testamentów staropolskich - zarys problematyki, w: Edytorstwo źródet: różne drogiwspólny cel, Kraków 2017, s. 35-47

- Gazetowy magnat, „Miesięcznik społeczno-kulturalny Kraków” nr 10 (167), październik 2018, s. 66-68

- Jak powstawat Kopiec Kościuszki w Krakowie - jego dzieje w czasach Rzeczpospolitej Krakowskiej, „Krakowski Rocznik Archiwalny”, R. 22: 2017 [wyd.2018], s.45-63

- „Koncept z kalendarza”. Krakowskie kalendarze epoki nowożytnej, „Miesięcznik społeczno-kulturalny Kraków" nr 1 (159), styczeń 2018, s. 42-45

- Ostatnia wola z inwokacją do Boga. O staropolskich testamentach, „Mówią Wieki. Magazyn historyczny", R. 2018, nr 5, s. 35-38

- Pamiatki po Adamie Mickiewiczu w Krakowie (wybór). Biblioteka Naukowa PAU i PAN w Krakowie, w: Adam Mickiewicz w Krakowie. Katalog wystawy, Kraków 2018, s. 169-170

- Powiew wolności 1848, „Miesięcznik społeczno-kulturalny Kraków” nr 3 (161), marzec 2018, s. 64-67

- Prasa socjalistyczna wydawana w Krakowie w latach 1900-1914. Zarys problematyki, w: Polityka i politycy w prasie XX i XXI wieku. Prasa organizacji politycznych, Białystok 2017, s.117-127

- Schytek c.k. monarchii. Ostatnia wizyta cesarza w Krakowie, ,, Miesięcznik społeczno-kulturalny Kraków" nr 5 (151), maj 2017, s. 53-55

- Szkoła rozumnych obywateli - Gimnazjum Wołyńskie w Krzemieńcu (1805-1831), „Wiadomości Historyczne z Wiedzą o Społeczeństwie”, R. 61: 2018, nr 3, s. 4-8

- Śluby w XIX-wiecznym Krakowie, „Miesięcznik społeczno-kulturalny Kraków” nr 2 (160), luty 2018, s. 34-37

- Wojna światowa 1914-1918. Moje wspomnienia i przeżycia bojowe, skreślit Emanuel de Charlenz Hohenauer..., oprac. E. Danowska, Kraków 2018, ss. 76, ilustr.

- „Wojskowa stużba moja”. Wspomnienia księdza Jana Twardowskiego, żotnierza 13. Galicyjskiego Pułku Piechoty „Guidobalda Starhemberga”, zwanego „,Krakowskimi Dziećmi”, „Rocznik Biblioteki Naukowej PAU i PAN w Krakowie”, R. 63: 2018, s. 23-69 (wspólnie z Piotrem Świątczakiem)

- Włodzimierza Tetmajera droga do niepodległości, „Miesięcznik społeczno-kulturalny Kraków" nr 11 (168), listopad 2018, s. 25-27

- Z dziejów krakowskiego rzemiosła, w: 90 lat Małopolskiej Izby Rzemiosta i Przedsiębiorczości w Krakowie, Kraków 2018, s. 68-70

- recenzja Izabela Krasińska, Polskojęzyczne czasopisma abstynenckie w latach 1843-1914, Kraków 2018, ss. 549, „Rocznik Bibliologiczno-Prasoznawczy”, T. 10/21: 2017, s. 187-190.

Karolina Grodziska

- Cmentarz na Pasterniku. W 110 rocznice jego utworzenia, „Rocznik Biblioteki Kraków”, R. 2: 2018, s. 43-61

- Grodziski Stanistaw (1889-1946), adwokat w Krakowie, w: Stownik biograficzny adwokatów polskich, T. 3: 2018, z. 1, s. 138-140 (wspólnie ze Stanisławem Grodziskim) 
- Jan Kazimierz Tetmajer w świetle spuścizny rękopiśmiennej w Bibliotece Naukowej PAU i PAN w Krakowie, ,, Rocznik Biblioteki Naukowej PAU i PAN w Krakowie”, R. 63: 2018, s. $119-128$

- Jana Zahradnika wierszyki polityczne, w: Nihil sine litteris scripta in honorem professoris Venceslai Walecki, Kraków 2017, s. 271-280

- Katarzyna Stoniowska, zapomniana lwowianka, „Cracovia Leopolis”2018, nr 3 (92), s. 57-59

- Miasto 1257-1493, w: Tysiąc skarbów Krakowa. Dzieje i sztuka, Międzynarodowe Centrum Kultury, Kraków 2018, s. $94-109$

- Od Biblioteki, słowo wstępne do reprintu: Józef Łepkowski, Przegląd krakowskich tradycyj, legend, nabożeństw, zwyczajów, przysłów i właściwości, Kraków 2018, s. III-IX

- Od redakcji, „Rocznik Biblioteki Naukowej PAU i PAN w Krakowie”, R. 63: 2018, s. 3-8

- Pisz pan, panie Wik!, „Cracovia Leopolis” 2018, nr 1 (90), s. 32-34

- Rocznik Biblioteki Naukowej PAU i PAN w Krakowie, R. 63: 2018, ss. 422, redakcja tomu (wspólnie z E. Fiałek)

- Sportowe tematy w sowieckim Lwowie. Na przykładzie twórczości rzeźbiarskiej Janiny Reichert-Toth i Fryderyka Totha z lat 1939-1946, „Cracovia Leopolis” 2017, nr 4 (89), s. 45-47

- Tęsknota za białym dworkiem. Zapomniane wiersze Stanisława Maykowskiego, „Cracovia Leopolis" 2018, nr 4 (93), s. 52-54

- W 155-lecie bitwy miechowskiej, w: „Ojczyźnie naszej, Polsce, bądźmy wierni”. Bitwa miechowska 17 lutego 1863 roku w relacjach uczestników powstania styczniowego i świadków zniszczenia miasta, wybór i oprac. Maria Słuszniak, Miechów 2018, s. 13-15

- St. Grodziski, Na Orlim Szlaku, Kraków 2018, ss. 230, opieka redakcyjna i wybór ilustracji

- St. Grodziski, Klio, córka Mnemosyne, kelnerka z Kopciuszka. Kraków 1968-1982, Kraków 2018, wyd. 2, poprawione i uzupełnione, ss. 333, opieka redakcyjna i wybór ilustracji

- Kalendarz PAU i Biblioteki na rok 2019, wybór ilustracji i opieka redakcyjna.

Elżbieta Knapek

- Udziat kanoników krakowskich w zarzadzie diecezja za pontyfikatu Wojciecha Jastrzębca, w: Wojciech Jastrzębiec - w stużbie monarchii i Kościoła, Katowice 2018, s. 161-169.

Małgorzata Kre mer

- Biblioteka Naukowa PAU i PAN w Krakowie, Sprawozdanie PAN, R. 2017 (płyta CD)

- Sprawozdanie z działalności Biblioteki Naukowej PAU i PAN w Krakowie za okres od 1 I do 31 XII 2017, „Rocznik Biblioteki Naukowej PAU i PAN w Krakowie”, R. 63: 2018, s. $357-380$.

Wojciech Lipowski

- Szczęsny Mysłowicz, filmowy dokumentalista międzywojennego Krakowa, „Rocznik Biblioteki Naukowej PAU i PAN w Krakowie”, R. 63: 2018, s. 333-346.

Jan Motyka

- O wystawie, w: Seria oryginalnych grafik artystów polskich w opracowaniu Aliny Kalczyńskiej 1984-2014, Kraków 2018, s. 5-6

- Modernizm udomowiony. Współczesna architektura chińska, Sprawozdanie z działalności Muzeum Sztuki i Techniki Japońskiej Manggha 2017, s. 21-27.

Anna O1szewska

- Wyszukiwanie wizualne w obiegu kultury: strategie projektowe, przykład systemu PrintExplorer, „Rocznik Biblioteki Naukowej PAU i PAN w Krakowie”, R. 63: 2018, s. 381-387 (z Joanną Gancarczyk) 
- Senster 2.0. Cultural contex of media art curatorship, w: Proceedings of EVA London 2018. EVA London. Electronic Visualisation and the Arts. BCS London 9-13 July 2018. (Conference) Editors: Jonathan P. Bowen, Graham Diprose, Nick Lambert.

Bartłomiej Stempin

- Pojednanie polsko-ukraińskie w myśli politycznej prezydentów Polski Aleksandra Kwaśniewskiego i Lecha Kaczyńskiego, w: Partnerstwo polsko- ukraińskie: bezpieczeństwo, polityka, społeczeństwo, Olsztyn, Lwów 2018, s. 117-129.

Piotr Świątczak

- „Wojskowa stużba moja”. Wspomnienia księdza Jana Twardowskiego, żotnierza 13. Galicyjskiego Pułku Piechoty ,, Guidobalda Starhemberga”, zwanego „Krakowskimi Dziećmi”, „Rocznik Biblioteki Naukowej PAU i PAN w Krakowie”, R. 63: 2018, s. 23-69 (wspólnie z Ewą Danowską).

Maria Urgac z

- „Przeżywamy wielkie dni dziejowe”. Obraz rodzacego się niepodległego państwa polskiego w „Dzienniczku z czasów wojny 1914-1921” Franciszka Dudy, ,Rocznik Biblioteki Naukowej PAU i PAN w Krakowie", R. 63: 2018, s. 71-118

- „Stanęli w potrzebie”. Stużba wojskowa przyszłych członków polskiej Akademii Umiejętności w latach 1914-1920, „Rocznik Biblioteki Naukowej PAU i PAN w Krakowie”, R. 63: 2018, s. 9-21. 